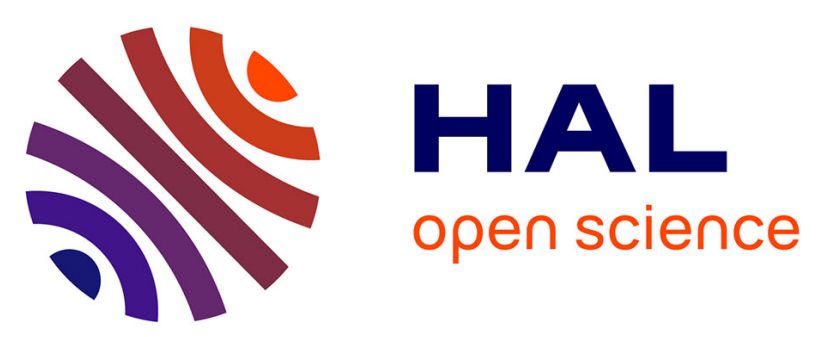

\title{
Expression of annexin I, II, V, and VI by rat osteoblasts in primary culture: Stimulation of annexin I expression by dexamethasone
}

Françoise Suarez, Bernard Rothhut, Christine Coméra, Lhousseine Touqui, Françoise Russo Marie, Caroline Silve

\section{To cite this version:}

Françoise Suarez, Bernard Rothhut, Christine Coméra, Lhousseine Touqui, Françoise Russo Marie, et al.. Expression of annexin I, II, V, and VI by rat osteoblasts in primary culture: Stimulation of annexin I expression by dexamethasone. Journal of Bone and Mineral Research, 1993, 8 (10), pp.1201-1210. 10.1002/jbmr.5650081007 . hal-02656032

\section{HAL Id: hal-02656032 \\ https://hal.inrae.fr/hal-02656032}

Submitted on 29 May 2020

HAL is a multi-disciplinary open access archive for the deposit and dissemination of scientific research documents, whether they are published or not. The documents may come from teaching and research institutions in France or abroad, or from public or private research centers.
L'archive ouverte pluridisciplinaire HAL, est destinée au dépôt et à la diffusion de documents scientifiques de niveau recherche, publiés ou non, émanant des établissements d'enseignement et de recherche français ou étrangers, des laboratoires publics ou privés. 


\title{
Expression of Annexin I, II, V, and VI by Rat Osteoblasts in Primary Culture: Stimulation of Annexin I Expression by Dexamethasone
}

\author{
FRANÇOISE SUAREZ, ${ }^{1}$ BERNARD ROTHHUT, ${ }^{2}$ CHRISTINE COMERA, ${ }^{2 .}{ }^{*}$ \\ LHOUSSEINE TOUQUI,${ }^{3}$ FRANÇOISE RUSSO MARIE, ${ }^{2}$ and CAROLINE SILVE'
}

\begin{abstract}
To determine whether rat osteoblasts synthesize proteins of the annexin family and to evaluate the extent to which glucocorticoids modulate the expression of annexins by these cells, osteoblasts were grown in primary cultures in the absence or presence of dexamethasone, and the expression of annexins was evaluated by immunoblotting using polyclonal antibodies against human annexins. Four different annexins (I, II, V, and VI) were found to be expressed by rat osteoblasts. The expression of annexin I, but not the other annexins studied, was increased in osteoblasts cultured in the presence of dexamethasone (173 $\pm 33 \%$ increase comparing untreated cells and cells treated for 10 days with $5 \times 10^{-7} \mathrm{M}$ dexamethasone). Increased expression of annexin I was observed after the third day of exposure to dexamethasone and rose thereafter until day 10; annexin I expression increased with dexamethasone concentrations above $10^{-10} \mathrm{M}$ throughout the range of concentrations studied. The increase in annexin I protein was associated with an increase in annexin I mRNA and was completely blocked by the concomitant addition of the glucocorticoid receptor antagonist $R U$ 38486. The increase in annexin I content following dexamethasone treatment was associated with an increase in alkaline phosphatase activity and PTH-induced cAMP stimulation, whereas phospholipase $A_{2}$ activity in the culture medium was reduced to undetectable levels. The finding that four annexins are expressed in rat osteoblasts in primary culture raises the possibility that these proteins could play an important role in bone formation by virtue of their ability to bind calcium and phospholipids, serve as $\mathrm{Ca}^{2+}$ channels, interact with cytoskeletal elements, and/or regulate phospholipase $A_{2}$ activity. In addition, the dexamethasone-induced increase in annexin I may represent a mechanism by which glucocorticoids modify osteoblast function.
\end{abstract}

\section{INTRODUCTION}

$\mathrm{T}$ HE PRODUCTION OF A MINERALIZED ORGANIC MATRIX by the osteoblasts depends on a series of complex events, including the synthesis of matrix proteins, the specific organization of this matrix necessary to create a milieu propitious for the deposition of mineral, and subsequent mineral deposition. (1.2) A number of osteoblast products and bone matrix components necessary for bone formation have been characterized, including bone sialoproteins I and II (cell attachment), ${ }^{(3.4)}$ bone morphogenic proteins (promotion of bone formation), (5) alkaline phosphatase and osteonectin (bone mineralization), ${ }^{(0,7)}$ and osteocalcin (bone remodeling). ${ }^{(8)}$ Although studies evaluating the specific function of these components in the production of the mineralized organic matrix have improved our understanding of this process, important gaps remain in our knowledge of bone formation. In particular the definition of osteoblast products necessary for the initiation of bone mineralization is far from complete.

'CNRS URA 583, Hôpital Necker Enfants Malades, Paris, France.

INSERM U 332, ICGM, Paris, France.

'Unité des Venins, Institut Pasteur, Paris, France.

*Present affiliation: Laboratoire de Toxicologie et Pharmacologie, INRA, Toulouse, France. 
In recent years, independent approaches have led to the identification of a family of proteins, "annexins," which are characterized by their ability to bind calcium and interact with phospholipids in a calcium-dependent fashion. ${ }^{(9-11)}$ The annexins (originally designated lipocortin, calpactin, endonexin, and chromobindin)(12) are structurally related and appear to be derived from a common ancestral gene. ${ }^{(9)}$ Annexins are present in a number of different tissues, including cartilage and matrix vesicles isolated from chondrocytes. ${ }^{(13-13)}$ Although the presence of annexins in bone or bone cells in culture has not been reported, these proteins could play a role in mineralization by virtue of their ability to bind to calcium and phospholipids. For example, calcium acid phospholipid complexes have been found to be concentrated in mineralizing connective tissue and have been found to promote hydroxyapatite deposition. (16-18) Other roles for annexins in the homeostasis of bone are also possible. The phenotype of osteoblasts is subject to regulation by glucocorticosteroids, which are potent modulators of bone cell metabolism and function in vivo ${ }^{(19)}$ and in vitro. ${ }^{(20-22)}$ One member of the annexin family (lipocortin I) was defined as a glucocorticoid-inducible phospholipase $\mathbf{A}_{\mathbf{2}}$ inhibitor. ${ }^{(23-25)}$ In this context, some of the effects of glucocorticoids on bone, including their effects on arachidonic acid metabolism by osteoblasts, could be mediated through the regulation of such annexins.

The purpose of this study was threefold. First, we determined whether osteoblasts in primary culture synthesize members of the annexin family. Second, we evaluated the extent to which glucocorticosteroids modulate the expression of annexins by these cells, and compared these changes to those observed in two other characteristics of osteoblast activities, parathyroid hormone (PTH)-induced cAMP production and alkaline phosphatase activity. Finally, in an attempt to identify the mechanism by which glucocorticosteroids modulate arachidonic acid metabolism in osteoblasts, we sought evidence that annexins modify osteoblast phospholipase $\mathbf{A}_{\mathbf{2}}$ activity.

\section{MATERIALS AND METHODS}

\section{Primary rat osteoblast cultures}

Osteoblasts were isolated from the calvariae of newborn rats (Charles River, Saint Aubin les Elbeuf, France) by sequential enzymatic digestion, as previously described for mice, ${ }^{(26)}$ with slight modifications. The central parts of parietal bones were removed aseptically and the periosteal layers carefully stripped off. Parietal bones were extracted by stirring for 15 minutes at $37^{\circ} \mathrm{C}$ in Ca-free phosphatebuffered saline containing $5 \mathrm{mM}$ EDTA and $0.05 \%$ tryp$\sin$, followed by three incubations of 20 minutes in phosphate-buffered saline containing $0.1 \%$ collagenase (Sigma, $\mathrm{St}$. Louis, MO). The cells released during the last two incubations were combined and cultured. Cells were plated at 2 $\times 10^{4}$ cells $/ \mathrm{cm}^{2}$ in $0.25 \mathrm{ml} / \mathrm{cm}^{2}$ of Dulbecco's modified Eagle's medium (Eurobio, les Ullis, France) supplemented with $100 \mathrm{U} / \mathrm{ml}$ of penicillin $\mathrm{G}, 50 \mu \mathrm{g} /$ of streptomycin, 1 $\mathrm{mM}$ glutamine (complete medium), and $20 \%$ fetal calf serum (FCS) and cultured at $37^{\circ} \mathrm{C}$ in $95 \%$ air and $5 \%$ $\mathrm{CO}_{2}$. The medium was replaced $48 \mathrm{~h}$ later and every third day thereafter with complete medium containing $10 \%$ FCS. Cells reached confluence on day 4-5 of culture.

\section{Pretreatment of the cells}

Dexamethasone (Sigma; $5 \mu \mathrm{l} / \mathrm{ml}$ culture medium, $5 \times$ $10^{-12}$ to $5 \times 10^{-6} \mathrm{M}$ final concentration) was added to osteoblast cultures for various times. Fresh dexamethasone was added at each medium change. In some experiments, $50 \mu \mathrm{l} / \mathrm{ml}$ culture medium of $1 \times 10^{-4} \mathrm{M}$ RU 38486 (kindly provided by Roussel Uclaf Laboratories, Romainville, France, $5 \times 10^{-6} \mathrm{M}$ final concentration) was added to the cultures in addition to dexamethasone. Stock solutions of dexamethasone and RU $38486\left(10^{-2} \mathrm{M}\right.$ in ethanol) were stored at $-20^{\circ} \mathrm{C}$, and intermediate dilutions were performed in medium without serum. Control cultures, maintained in parallel, received 5 or $55 \mu$ l solvent alone (ethanol diluted 1:100 in medium without serum).

\section{Sodium dodecyl:sulfate (SDS)-polyacrylamide gel electrophoresis and immunoblotting}

Cells were grown in $28 \mathrm{~cm}^{2}$ culture dishes and treated with dexamethasone as described. To collect the cells, culture dishes were placed on ice, washed twice with $3 \mathrm{ml}$ icecold Dulbecco's phosphate-buffered saline, scraped in 200 $\mu \mathrm{l}$ Laemmli SDS-sample buffer, ${ }^{(27)}$ and immediately boiled for 10 minutes. Samples were stored at $-20^{\circ} \mathrm{C}$. The protein content was determined on cells grown in dishes of the same size and cultured in parallel. Protein $(100 \mu \mathrm{g})$ was loaded on SDS-polyacrylamide gels.

SDS-polyacrylamide gel electrophoresis was performed according to Laemmli ${ }^{(27)}$ on $12.5 \%$ acrylamide gels (1.5 $\mathrm{mm}$ thick). The molecular weight of proteins was determined by comparison to migration of standard proteins (Pharmacia-LKB), which were electrophoresed in parallel. The separated proteins were then transferred from the gel to nitrocellulose membranes (HAHY 304 FO, Millipore) according to Burnette(28) using an electroblotting apparatus (Pharmacia-LKB 2117-250 Novablot) operated at constant current $(250 \mathrm{~mA})$ for $2.5 \mathrm{~h}$ in $20 \mathrm{mM}$ Tris-base, 150 $\mathrm{mM}$ glycine and $20 \%$ methanol. At the end of the transfer, nitrocellulose membranes were stained with india ink $(1 \mu l$ india ink per $\mathrm{ml}$ of $50 \mathrm{mM}$ Tris and $150 \mathrm{mM} \mathrm{NaCl}$ ) or with $0.2 \%$ Ponceau red (Serva, 33429) in 3\% trichloroacetic acid for 10 minutes and incubated in $50 \mathrm{mM}$ Tris, $150 \mathrm{mM}$ $\mathrm{NaCl}$, and $5 \%$ skimmed powdered milk (TNM) for I h at $37^{\circ} \mathrm{C}$ with constant shaking. Antisera against annexins (see later) were diluted (1:500) in $10 \mathrm{ml}$ TNM and incubated with membranes for $15 \mathrm{~h}$ at $4^{\circ} \mathrm{C}$ with constant shaking. Following five washes in TNM, the blot was incubated for 30 minutes at room temperature with ${ }^{125}$ I-labeled protein $\mathrm{A}$ diluted in $15 \mathrm{ml}$ TNM $\left(10^{5} \mathrm{cpm} / \mathrm{ml}\right.$, specific activity $\cong 24$ $\mathrm{mCi} / \mathrm{mg}$ ), washed four more times with TNM, and dried between sheets of filter paper; autoradiography of the dried blot was performed for $4-7$ days at $-80^{\circ} \mathrm{C}$. Strips of the blots that displayed bands on the autoradiograms were excised and the amount of radioactivity was quantified 
using a gamma counter. Radioactivity meas'ıred in strips of the blots not displaying bands was subtracted as background.

Polyclonal antibodies were raised in rabbits by popliteal lymph node injection ${ }^{(29)}$ of annexins I, V, and VI purified from human placenta. ${ }^{(30.31)}$ Cross-reactivity between the different antisera was less than $5 \%$. Antibody against annexin II was a gift from J.C. Cavadore (INSERM U 249, CNRS LP 8402, Montpellier, France).

\section{Northern blot analysis}

Cells were grown in $69 \mathrm{~cm}^{2}$ culture dishes and treated with dexamethasone as described. Total cellular RNA was isolated with guanidinium thiocyanate followed by centrifugation in cesium chloride gradients. ${ }^{(32)}$ RNA $(10 \mu \mathrm{g})$ was electrophoresed in a $1 \%$ agarose gel containing $0.45 \mathrm{M}$ formaldehyde ${ }^{(32)}$ in $20 \mathrm{mM}$ MOPS (3-( $\mathrm{N}$-morpholino) propane sulfonic acid) buffer at $160 \mathrm{~V}$ for $1 \mathrm{~h}$, transferred to Nytran nylon membranes (Schleicher and Schuell, NY), and dried for $2 \mathrm{~h}$ at $80^{\circ} \mathrm{C}$. Blots were hybridized with cDNA of human annexins I and VI (kindly provided by Barbara Wallner, Biogen Research Corporation, Cambridge, MA), which were labeled by random priming $\left(1.5 \times 10^{7} \mathrm{dpm} / 25 \mathrm{ng} \mathrm{cDNA}, 10^{6} \mathrm{cpm} /\right.$ $\mathrm{ml}$ ) and denatured by heating to $100^{\circ} \mathrm{C}$ for 10 minutes before use. Prehybridization $\left(30\right.$ minutes at $65^{\circ} \mathrm{C}$ ) and hybridization (overnight, $65^{\circ} \mathrm{C}$ ) were done in $50 \mathrm{mM}$ PIPES, pH 6.5, 50 mM sodium phosphate, $1 \mathrm{mM}$ EDTA, $100 \mathrm{mM} \mathrm{NaCl}$ and $5 \%$ SDS. ${ }^{(33)}$ Blots were then washed in standard saline citrate (SSC) and $5 \%$ SDS, first in $20 \mathrm{ml}$ for 20 mirutes at room temperature and again in $400 \mathrm{ml}$ for 30 minutes at $65^{\circ} \mathrm{C}$. To ensure that the total amount of RNA transferred was similar for each sample, the blots were hybridized with $\gamma^{32}$ P-labeled $28 S$ RNA probe as described by Barbu and Dautry. ${ }^{(34)}$ Blots were then dried and autoradiographed for $24 \mathrm{~h}$.

\section{Measurement of phospholipase $A_{2}$ activity}

Cells were grown in $69 \mathrm{~cm}^{2}$ culture dishes: and treated with dexamethasone as indicated earlier. After 10 days in culture, medium was collected, cells were scraped in $2 \mathrm{ml}$ culture medium without serum, and both medium and cells were stored at $-20^{\circ} \mathrm{C}$. On the day of the assiay, cells were lysed at $4^{\circ} \mathrm{C}$ by ultrasonication $(30 \mathrm{~s}, 150 \mathrm{~W})$ using an MSE sonifier. Phospholipase $A_{2}$ activity was measured in culture medium and cell homogenates using a fluorometric assay as described by Radvanyi et al. ${ }^{(35)}$ The fluorescent substrate [1-palmitoyl-2-(10-pyrenyldecanoyl)-sn-glycero3-monomethyl phosphatidic acid; Interchim, Montluçon, France] was dried under nitrogen and suspended in ethanol at $0.2 \mathrm{mM}$. Vesicles were prepared by mixing the ethanol solution of fluorescent phospholipid with an aqueous medium for 2 minutes. The reaction solution was prepared by introducing sequentially into a $4 \times 10 \mathrm{~mm}$ disposable plastic cuvette $980 \mu \mathrm{l}$ buffer $(100 \mathrm{mM}$ Tris- $\mathrm{HCl}, 1 \mathrm{M} \mathrm{NaCl}$, and $1 \mathrm{mM}$ EGTA, pH 7.5), $10 \mu$ substrate $(2 \mu \mathrm{M}$ final concentration), and $10 \mu \mathrm{l}$ of a $10 \%$ fatty acid-free bovine serum albumin solution $(0.1 \%$ final concentration); aliquots of cellular homogenates or medium $(10-50 \mu \mathrm{l})$ were introduced into the cuvettes and allowed to equilibrate at $37^{\circ} \mathrm{C}$ for 1 minute. The reactions were then initiated by the addition of $\mathrm{CaCl}_{2}$ at $10 \mathrm{mM}$ (final concentration). The fluorescence measurements were performed with a Jobin et Yvon JY3D spectrofluorometer equipped with a Xenon lamp. The fluorescence intensity was monitored using excitation and emission wavelengths of 345 and $398 \mathrm{~nm}$, respectively, and a slit width of $4 \mathrm{~nm}$. The final ethanol concentration was less than $0.1 \%$ and had no effect on the assay. Phospholipase $A_{2}$ activity measured in medium without serum and in medium containing 10\% FCS was used as a blank for phospholipase $\mathbf{A}_{2}$ activity in cells and medium, respectively. Results are expressed as pmol hydrolyzed substrate/ minute/mg protein.

\section{cAMP cellular content}

Cells were grown in 24-well culture plates and treated for 10 days with dexamethasone as before. Stimulation of cAMP production was performed for 10 minutes at room temperature in the presence of $1 \mathrm{mM}$ isobutyl-1-methylxanthine (Sigma) and extracted with ethanol as previously described. ${ }^{\{36\}}$ cAMP production was determined as previously described ${ }^{(36)}$ using a modification of the Gilman pro-

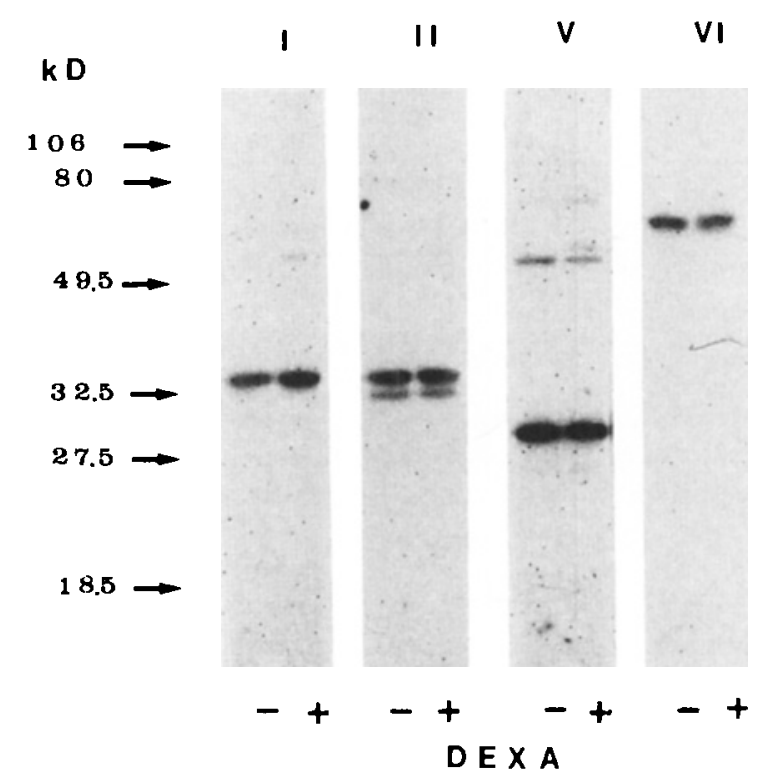

FIG. 1. Expression of annexin I, II, V, and VI in osteoblasts. Effect of dexamethasone. Western blots of annexin I, II, V, and VI were detected by Western blotting in protein extracts from osteoblasts cultured in the absence $(-)$ or in the presence $(+)$ of $5 \times 10^{-7} \mathrm{M}$ dexamethasone for 10 days. Osteoblast cultures, dexamethasone treatment, SDSpolyacrylamide gel electrophoresis, and Western blot analysis of annexins were performed as described in Materials and Methods. Protein $(100 \mu \mathrm{g})$ was electrophoresed in each lane. In addition to annexin V, material with a higher molecular weight (MW) was recognized by the annexin $\mathrm{V}$ antibodies. The MW of this cross-reactive material does not correspond to that of any annexin described, and we have no indication of its nature. The intensity of this band was very low compared to that given by annexin $V$. The data reported are representative of two independent experiments. 
tein binding assay ${ }^{(37)}$ in which human erythrocytes are used as the source of the cAMP binding protein. ${ }^{(38)} \mathrm{Re}$ sults are expressed as picomoles cAMP $/ 100 \mu \mathrm{g}$ protein.

\section{Cellular alkaline phosphatase activity}

Cells were grown in 12-well culture plates and treated with dexamethasone as described for 2-10 days. At the end of the culture period, medium was aspirated and the plates were stored at $-20^{\circ} \mathrm{C}$. On the day of the assay, cells from each dish were scraped into $1 \mathrm{ml}$ freshly prepared solution containing $8.5 \mathrm{~g}$ saccharose and $100 \mu \mathrm{l}$ Triton X-100/100 $\mathrm{ml}$ water. Cells were sonicated for $20 \mathrm{~s}$ on ice and centrifuged for 10 minutes at $2500 \mathrm{rpm}$ at $4^{\circ} \mathrm{C}$, and alkaline phosphatase activity was measured in the supernatant using $p$-nitrophenyl phosphate as a substrate (Sigma). Aliquots $(100 \mu \mathrm{l})$ of supernatant were incubated for $1 \mathrm{~h}$ at $37^{\circ} \mathrm{C}$ in the presence of $1 \mu \mathrm{mol}$ substrate, $0.625 \mu \mathrm{mol}$ $\mathrm{MgCl}_{2}$, and $25 \mu \mathrm{mol}$ glycine in a total volume of $500 \mu \mathrm{l}$ at $\mathrm{pH}$ 10.5. The reaction was stopped by adding $2.5 \mathrm{ml} / \mathrm{N}$ $\mathrm{NaOH}$ and $10 \mathrm{mM}$ EDTA. The amount of $p$-nitrophenol liberated was measured by absorbance at $405 \mathrm{~nm}$. Results are expressed as nmol $p$-nitrophenol released/minute/100 $\mu \mathrm{g}$ protein. Preliminary experiments demonstrated that alkaline phosphatase activity could not be detected in the culture medium.

\section{Protein content}

Protein content was estimated by the method of Lowry et al. ${ }^{\left({ }^{9}\right)}$ using bovine serum albumin as standard.

\section{Presentation of data}

Results are expressed as mean \pm standard deviation un less otherwise stated. All immunoblots and Northern blots were performed with equivalent amounts of cellular proteins and total RNA, 100 and $10 \mu \mathrm{g}$, respectively.

\section{RESULTS}

\section{Expression of annexins $I, I I, V$, and $V I$ in osteoblasts: Effect of dexamethasone}

Cellular proteins were extracted from rat osteoblasts and separated by electrophoresis and expression of annexins evaluated by immunoblotting. Proteins reactive with antisera specifically recognizing annexins I, II, V, and VI were expressed by these cells (Fig. 1). In each case, the molecular weights of these proteins corresponded closely to those previously reported for these four different annexins. In some cases, fainter bands of lower molecular weight were also reactive with these antibodies and presumably represented annexins that were partially degraded during the extraction procedures.

The expression of annexin I was significantly increased in osteoblasts cultured for 10 days in the presence of $5 \times$ $10^{-7} \mathrm{M}$ dexamethasone (Fig. 1). Quantitation of annexin I expression by determining ${ }^{125}$ I-labeled protein $\mathrm{A}$ bound to
Western blots demonstrated a $173 \pm 33 \%$ increase comparing dexamethasone-treated and untreated cells $(n=7)$. In contrast, dexamethasone treatment did not significantly change expression of annexin II, V, or VI (Fig. 1).

\section{Time course and dose-response curve of the induction of annexin I by dexamethasone}

The characteristics of the dexamethasone-induced stimulation of annexin I were further investigated by determining the kinetics and the dose-response curve of the dexamethasone effect. An increase in annexin I expression was not observed during the first 3 days of exposure of osteoblasts to $5 \times 10^{-7} \mathrm{M}$ dexamethasone (Fig. 2). Increased expression of annexin 1 was observed after the third day of exposure and thereafter rose progressively until day 10 , the latest time point evaluated.

When osteoblasts were cultured in the presence of dexamethasone at concentrations $<10^{-10} \mathrm{M}$, no increase in annexin I expression was observed after 10 days (Fig. 3). In

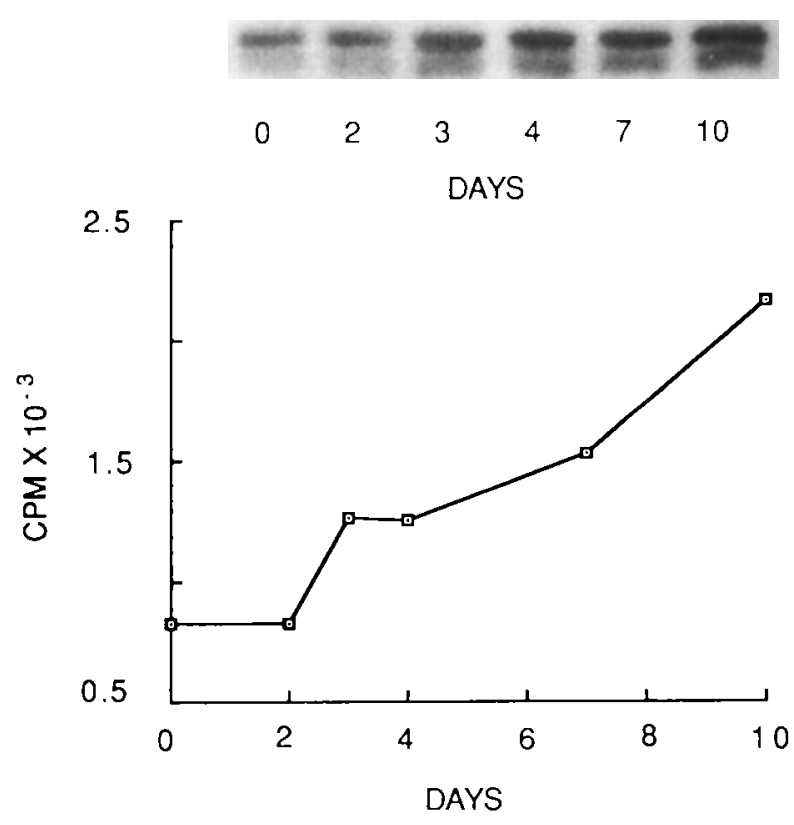

FIG. 2. Time course of the stimulation by dexamethasone of annexin I content in osteoblasts. Western blot analysis of annexin I (top) was performed in protein extracts from osteoblasts cultured in the presence of $5 \times 10^{-7}$ $M$ dexamethasone for the indicated times. The bands of lower molecular weight are likely to be proteolytic fragments of annexin I generated during the cell preparation for the protein blotting. Regions of the blots corresponding to annexin I, including the lower molecular weight bands, were excised, and the amount of radioactivity in each band was determined in a gamma counter (bottom). Osteoblast cultures, dexamethasone treatment, SDS-polyacrylamide gel electrophoresis, and Western blot analysis of annexin I were performed as described in Materials and Methods. Protein $(100 \mu \mathrm{g})$ was electrophoresed in each lane. Similar results were obtained in two independent experiments. 
general, annexin I expression increased with dexamethasone concentrations above $10^{-10} \mathrm{M}$ throughout the range of concentrations studied (Fig. 3).

In some experiments, the glucocorticoid receptor antagonist RU 38486 was added to the cultures in the presence or in the absence of dexamethasone to determine if the effect of dexamethasone was mediated through the activation of glucocorticoid receptors. The induction of annexin I by dexamethasone $\left(5 \times 10^{-7} \mathrm{M}, 10\right.$ days $)$ was totally blocked by the concomitant addition of $5 \times 10^{-6} \mathrm{M}$ RU 38486 (Fig. 4). RU 38486 alone had no effect on annexin I content (Fig. 4).

\section{Effect of dexamethasone on annexin mRNA}

To determine if the increase in annexin I protein induced by dexamethasone was associated with a similar increase in annexin I mRNA, cells were maintained for 7 and 10 days in the presence or absence of $5 \times 10^{-7} \mathrm{M}$ dexamethasone and the level of annexin I mRNA was examined by Northern blot analysis. Results demonstrated that the increase in annexin I protein was associated with an increase in annexin I mRNA, comparing dexamethasone-treated and untreated osteoblasts (Fig. 5). In agreement with the absence of effect of dexamethasone on the content of annexin VI in osteoblasts, no effect of dexamethasone on annexin VI mRNA was observed (Fig. 5).

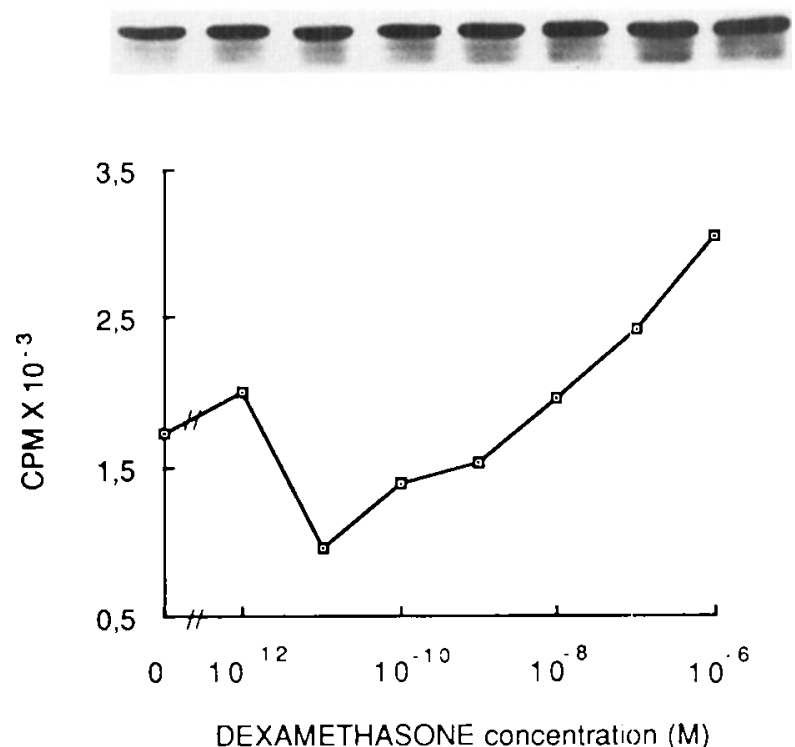

FIG. 3. Annexin I content in osteoblasts as a function of increasing concentrations of dexamethasone. Western blot analysis of annexin I (top) was performed in protein extracts from osteoblasts cultured in the presence of the indicated dexamethasone concentrations for 10 days. Regions of the blots corresponding to annexin I were excised, and the amount of radioactivity in each band was determined in a gamma counter (bottom). Osteoblast cultures, dexamethasone treatment, SDS-polyacrylamide gel electrophoresis, and Western blot analysis of annexin I were performed as described in Materials and Methods. Protein $(100 \mu \mathrm{g})$ was electrophoresed in each lane. The data reported are representative of two independent experiments.

\section{Effect of dexamethasone on other osteoblast phenotypic characteristics}

Alkaline Phosphatase Activity: Treatment of the cells with $5 \times 10^{-7} \mathrm{M}$ dexamethasone for 10 days resulted in an increase in alkaline phosphatase activity from 0.940 .23 to $2.21 \pm 0.10 \mathrm{nmol} / \mathrm{minute} / 100 \mu \mathrm{g}$ protein (mean $2 \mathrm{SD}$, $n=6$; Fig. 6). Like the increase in annexin 1 , maximal increase in alkaline phosphatase was observed at 10 days, the latest time studied, whereas shorter exposures had little or no effect on alkaline phosphatase activity.

PTH-Induced CAMP Production: Treatment of the cells with $5 \times 10^{-7} \mathrm{M}$ dexamethasone for 10 days also greatly enhanced the stimulation of cAMP production by PTH (14- and 106-fold stimulation in response to $240 \mathrm{nM}$ PTH, respectively, without and with dexamethasone treatment; Fig. 7).

Phospholipase $A_{2}$ Activity in Osteoblast Cultures: Because annexin I was first identified by its ability to inhibit phospholipase $A_{2}$, it was of interest to measure phospholipase $A_{2}$ in osteoblasts cultured in the absence or presence of dexamethasone. Phospholipase $A_{2}$ activity was easily detectable in both culture supernatants and cell sonicates of osteoblasts maintained in the absence of dexamethasone (Table 1). Interestingly, treatment of cells with $5 \times 10^{-7} \mathrm{M}$

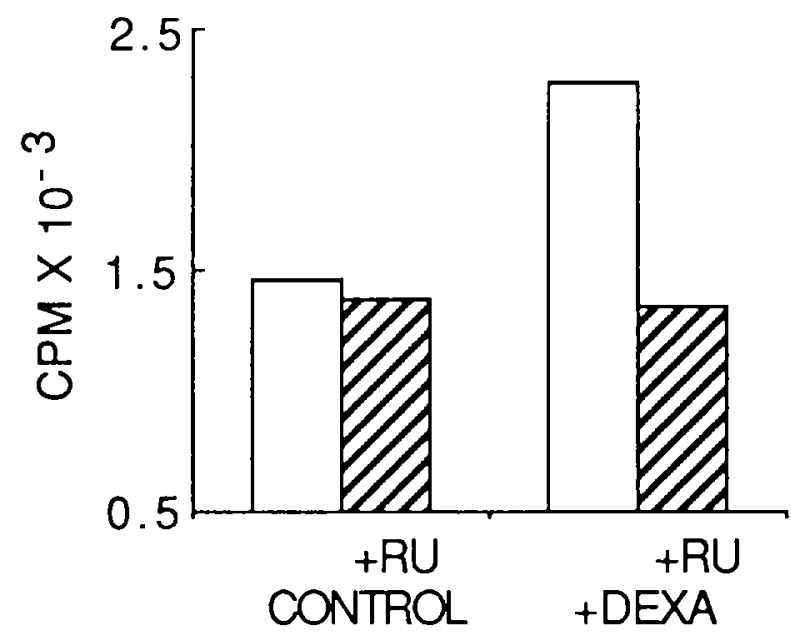

FIG. 4. Effect of RU 38486 on the stimulation by dexamethasone of annexin I expression in osteoblasts. Western blot analysis of annexin I (top) was performed in protein extracts from osteoblasts cultured in the absence (control) or in the presence of $5 \times 10^{-7} \mathrm{M}$ dexamethasone (+Dexa) and $5 \times 10^{-6} \mathrm{M}$ RU $38486(+\mathrm{RU})$ for 10 days. Regions of the blots corresponding to annexin I were excised, and the amount of radioactivity in each band was determined in a gamma counter (bottom). Osteoblast cultures, dexamethasone, and RU 38486 treatment, SDS-polyacrylamide gel electrophoresis, and Western blot analysis of annexin I were performed as described in Materials and Methods. Protein $(100 \mu \mathrm{g})$ was electrophoresed in each lane. The data reported are representative of two independent experiments. 


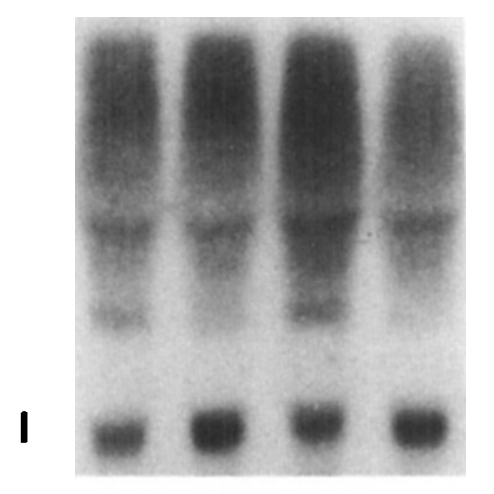

VI
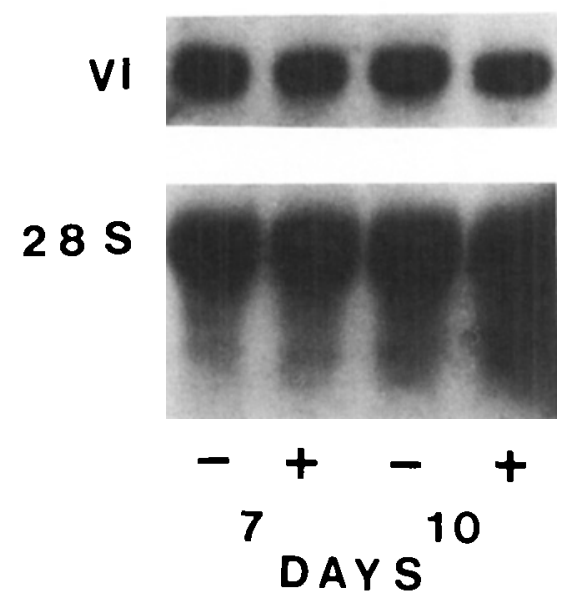

FIG. 5. Northern blot analysis of RNA from osteoblasts probed with cDNA for human annexins I and VI and a $28 S$ ribosomal RNA probe. Osteoblasts were cultured in the presence of $5 \times 10^{-7} \mathrm{M}$ dexamethasone for 7 and 10 days. Total cellular RNA was prepared using a cesium gradient, electrophoresed in a $1 \%$ agarose gel and transferred to Nytran nylon membranes, and blots were hybridized with radiolabeled probes as described in Materials and Methods. RNA $(10 \mu \mathrm{g})$ was electrophoresed in each lane.

dexamethasone for 10 days suppressed phospholipase $A_{2}$ activity in the culture medium to undetectable levels, whereas no consistent effect on cellular phospholipase $\mathbf{A}_{2}$ activity was observed (Table 1).

Total Cellular Protein: Dexamethasone treatment decreased the amount of total cellular protein in the cultures (35 \pm 6 and $24 \pm 5 \mu \mathrm{g} / \mathrm{cm}^{2}$, respectively, without and after dexamethasone treatment; $n=5, p<0.05$ ). The electrophoretic pattern of proteins obtained from osteoblasts cultured in the absence of dexamethasone and after treatment with $5 \times 10^{-7} \mathrm{M}$ dexamethasone for 10 days appeared similar both before and after transfer to nitrocellulose membranes, as demonstrated by the Coomassie blue staining of the SDS-polyacrylamide gels and the india ink staining of nitrocellulose membrane after transfer (Fig. 8).

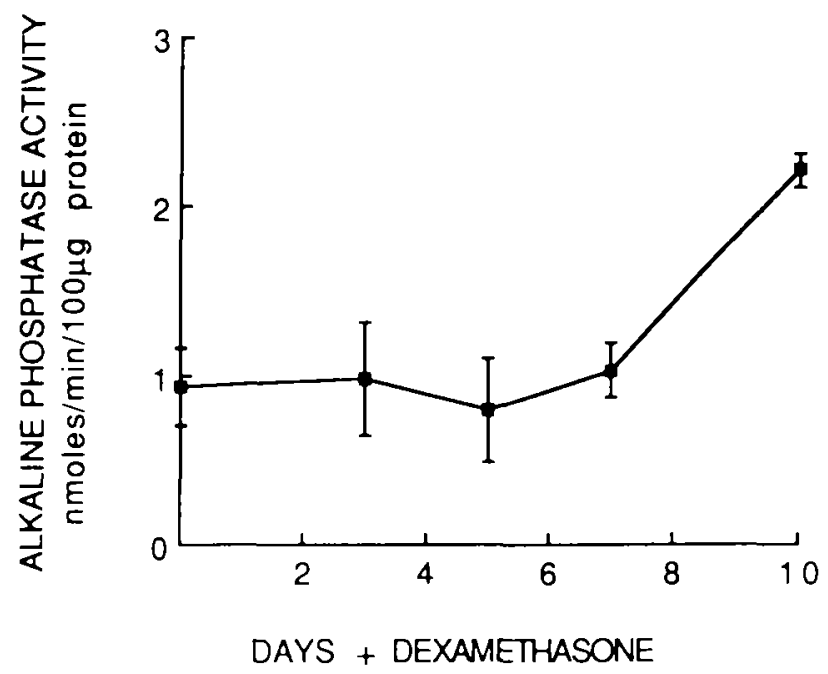

FIG. 6. Effect of dexamethasone on cellular alkaline phosphatase activity in osteoblasts. Osteoblasts were cultured for 10 days without dexamethasone or in the presence of $5 \times 10^{-7} \mathrm{M}$ dexamethasone for the indicated times, and cellular alkaline phosphatase activity was measured as described in Materials and Methods. Alkaline phosphatase activity measured in osteoblasts cultured for 10 days without dexamethasone is the value given at time 0 . Results are the mean $\pm \mathrm{SD}, n=6$.

\section{DISCUSSION}

This study demonstrates that four members of the annexin family, annexins I, II, V, and VI, are produced by rat osteoblasts maintained in primary cultures, and it is the first description of the expression of annexins by bone cells. Exposure of osteoblasts to $5 \times 10^{-7} \mathrm{M}$ dexamethasone results in an increase in the cellular content of annexin I and mRNA coding for this protein, whereas the cellular content of the other annexins studied was not modified. The increase in annexin I content following dexamethasone treatment was not an early event, however, but was associated with an increase in other activities considered typical of mature osteoblasts (alkaline phosphatase activity and PTH-induced cAMP stimulation).

\section{Annexins and bone formation}

Although annexins share structural and functional features, ${ }^{(9-11)}$ the presence of a unique $\mathrm{N}$-terminal sequence for each annexin suggests that each annexin has a specific role. In view of the previously described properties of different members of the annexin family, several possible mechanisms exist by which annexins could contribute to bone formation, none of which is mutually exclusive.

First, annexins share a 17 amino acid residue consensus sequence that is probably involved in $\mathrm{Ca}^{2+}$-dependent binding to anionic phospholipids. ${ }^{(10)}$ The ability of annexins to bind calcium and phospholipids could contribute to miner- 


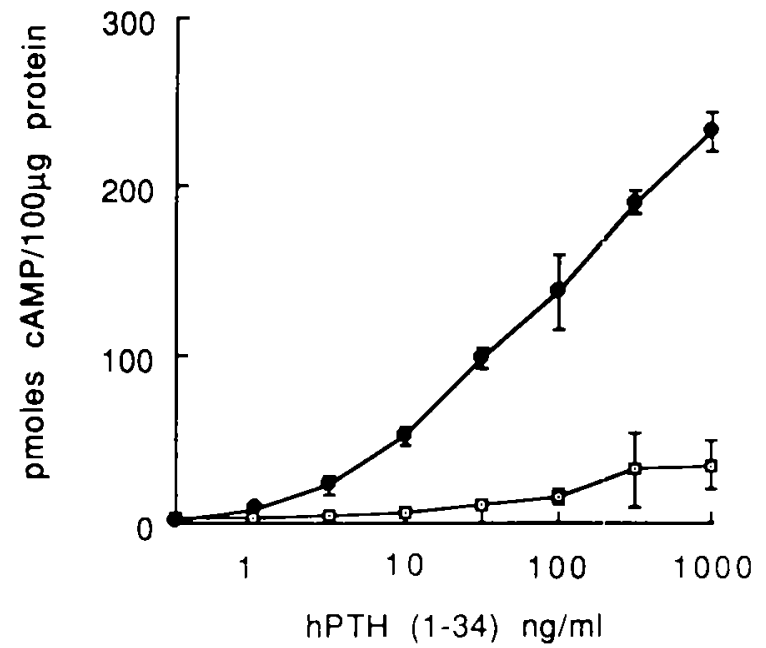

FIG. 7. Stimulation of cAMP production by increasing PTH concentrations in osteoblasts treated or not with dexamethasone. Osteoblasts were cultured in the absence or in the presence of $5 \times 10^{-7} \mathrm{M}$ dexamethasone for 10 days, and stimulation of cAMP production by the indicated concentration of PTH was performed as described in Materials and Methods. Results are the mean \pm SD of one representative experiment, performed in triplicate: untreated cells (open squares); dexamethasone-treated cells (closed circles). Similar results were obtained in a second experiment.

Table 1. Phospholipase $A_{2}$ Activity in the Medium and Cell Pellet of Osteoblasts Cultured in the Absence or Presence of $5 \times 10^{-7}$ M Dexamethasionea

\begin{tabular}{lccccc}
\hline & \multicolumn{2}{c}{ Medium } & & \multicolumn{2}{c}{ Cells } \\
\cline { 2 - 3 } \cline { 5 - 6 } Experiment & Control & + Dexa & & Control + Dexa \\
\hline 1 & 3.9 & $<0.1$ & 3.3 & 1.1 \\
2 & 1.67 & $<0.1$ & 1.5 & 1.6 \\
\hline
\end{tabular}

a Osteoblasts were cultured in the absence (control) or in the presence of $5 \times 10^{-7} \mathrm{M}$ dexamethasone (+ Dexa) fer 10 days, and medium and cellular phospholipase $A_{\mathbf{1}}$ activity was measured as described in Materials and Methods. Results are the mean of two determinations per experiment and are expressed as pmol hydrolyzed fluorescent substrate [1-palmitoyl-1-(10-pyren yldecanoyl)snglycero-3-monomethylphosphatidic acid]/minute/mig protein.

alization of bone matrix, as was previously suggested for the mineralization of cartilage. ${ }^{(13)}$ In this regard, annexins have been described as complexes to lipids in cartilage matrix vesicles, ${ }^{(14)}$ and calcium acid phospholipid complexes have been shown to promote the deposition of hydroxyapatite in vitro and in vivo. (16-18)

Second, different members of the annexin family have been found to bind to intracellular cytoskeletal elements [e.g., binding of annexins I, II, and VI to actin ${ }^{(25)}$ and tissue connective components [e.g., binding o: annexin $\mathrm{V}$ (anchorin CII) to type II collagen ${ }^{(15)}$. Furthermore, anchorin $\mathrm{CII}$ has been suggested as responsible for fibro-

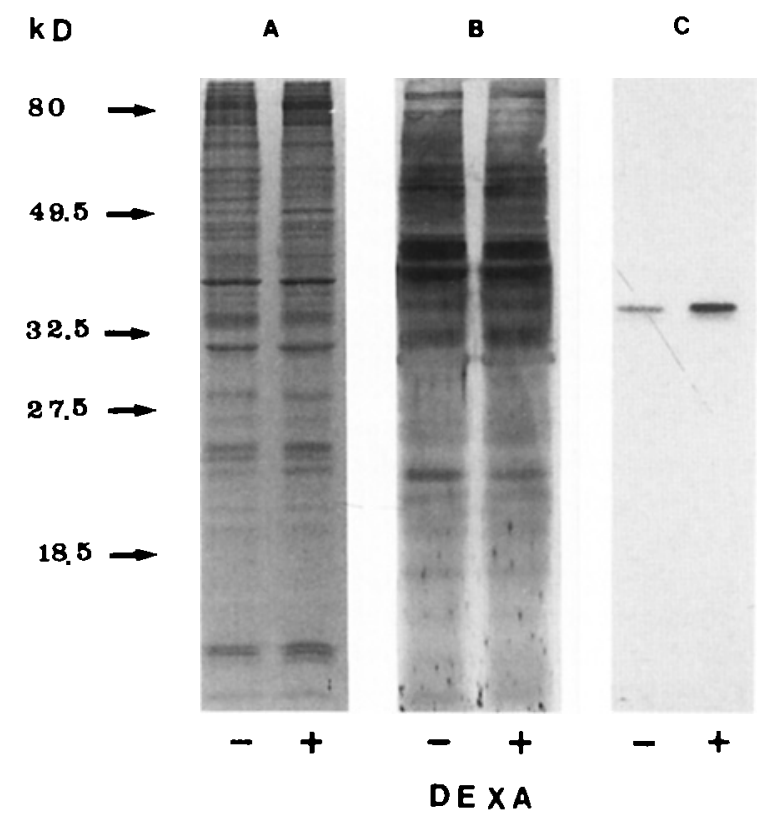

FIG. 8. Distribution of cellular proteins obtained from untreated $(-)$ and dexamethasone-treated $(+)$ osteoblast cultures. Proteins were separated by SDS-polyacrylamide gel electrophoresis. (A) Pattern of proteins as revealed by staining proteins in the gel with Coomassie blue R-250 and $(B)$ proteins after transfer to nitrocellulose membranes and stained with india ink. (C) Western blots of annexin I from the corresponding protein extracts. Osteoblast cultures, dexamethasone treatment, SDS-polyacrylamide gel electrophoresis, and Western blot analysis of annexin I were performed as described in Materials and Methods. Protein $(100 \mu \mathrm{g})$ was electrophoresed on each lane. A similar pattern was obtained in all experiments.

blast-collagen interactions, ${ }^{(40)}$ implying that it could bind to collagen types other than collagen type II, in particular collagen type I. Through such interactions, annexins could contribute to a variety of processes required for bone formation, such as budding of matrix vesicles from the plasma membranes of osteoblasts and the attachment of osteoblasts to extracellular collagen.

Third, annexin $\mathrm{V}$ has been shown to exhibit $\mathrm{Ca}^{2+}$ channel activity, ${ }^{(41)}$ consistent with the idea that annexin $\mathrm{V}$ could regulate $\mathrm{Ca}^{2+}$ transport in osteoblasts.

Finally, annexins could serve as regulatory proteins. For example, annexin I, previously called lipocortin I, was originally defined as a corticosteroid-inducible phospholipase $\mathbf{A}_{\mathbf{2}}$ inhibitor. ${ }^{\text {(23.24) }}$ We demonstrated in this study that phospholipase $A_{2}$ activity could be detected in both medium and cell layer of rat osteoblasts. It is possible that the striking reduction in phospholipase $A_{2}$ in the medium of cells treated with glucocorticoids resulted, at least in part, from the increase in annexin I observed in these cells. It should be stressed, however, that corticosteroid treatment had no consistent effect on intracellular phospholipase $A_{2}$ activity. Further studies are required to determine the role, if any, of annexin I in the regulation of phospho- 
lipase $A_{2}$ activity and to evaluate the consequences of dexamethasone-induced changes in phospholipase $A_{2}$ activity on osteoblast function.

\section{Dexamethasone and annexin I expression}

We found that the addition of dexamethasone to osteoblast cultures increased the expression of annexin I, but not of the other annexins, in a time- and concentration-dependent manner. The induction of annexin I by dexamethasone was blocked by the concomitant addition of the glucocorticoid receptor antagonist RU 38486, demonstrating that dexamethasone-induced annexin I RNA and protein synthesis occurred via the activation of the glucocorticoid receptor.

Conflicting data exist in the literature regarding the inducibility of annexin I by glucocorticoids. ${ }^{(23,24)}$ Steroid induction of annexin I has been observed consistently in monocytes incubated in vitro or recovered from animals or humans treated with steroids. In contrast, no induction of annexin I mRNA or protein has been demonstrated in most cell lines, including in $U 937$ cells $^{(42)}$ and primary cultures of human endothelial cells, ${ }^{(43)}$ although dexamethasone was found to increase both annexin I MRNA and protein in 3T3 fibroblasts. ${ }^{(44)}$ The discrepancy observed between these studies may be explained in part by the state of differentiation of the cells (45) and/or by the experimental design used to characterize the effect of dexamethasone. For instance, the effect of dexamethasone on annexin I synthesis in human endothelial cells was studied after $3 \mathrm{~h}$ of incubation of the cells in presence of the steroid, (43) but the effect of dexamethasone on 3T3 fibroblasts was observed after 4 days of culture in the presence of dexamethasone. (44) Consequently the term "induction" covers two different processes, a rapid induction, as described in monocytes, and a relatively slow induction generally associated with cellular differentiation, as described in $3 \mathrm{~T} 3 \mathrm{fi}-$ broblasts. The induction of annexin I content by dexamethasone in osteoblasts was never detected before 3 days of exposure to dexamethasone. The increase in annexin I was associated with an increase in cellular alkaline phosphatase activity and with a potentiation of the stimulation of cAMP production by PTH, as described for human bone cells, ${ }^{(46.47)}$ rodent osteoblastic cells, (48) and rat osteosarcoma cells. (49-52) Stimulation of PTH-induced cAMP production and alkaline phosphatase activity are two hallmarks of the osteoblastic phenotype. Such an effect of dexamethasone on osteoblast differentiation has been observed in studies in which dexamethasone has been shown to stimulate osteogenesis ${ }^{(20.22)}$ and the expression of bone matrix proteins associated with mineral tissue formation. (21) Thus, the induction of annexin I expression by dexamethasone may be part of a general effect of dexamethasone on osteoblast differentiation. It will be interesting to compare the regulation of annexin metabolism in cells cultured in the presence of factors thought to promote matrix deposition and mineralization, such as ascorbic acid and $\beta$-glycerophosphate.

In conclusion, we report the expression of annexins I, II, $\mathrm{V}$, and VI by rat osteoblasts in primary culture. Because of their biochemical properties and their specific regulation, this unique group of membrane-directed regulatory proteins are likely to play a significant role in the osteoblast function and bone metabolism. The demonstration that glucocorticoids strongly inhibit phospholipase $\mathbf{A}_{\mathbf{2}}$ activity release in the medium and increase the expression of annexin 1 may provide new insights into the mechanisms by which glucocorticoids modify osteoblast biology.

\section{REFERENCES}

1. Marks SC Jr, Popoff SN 1988 Bone cell biology: The regulation of development, structure, and function in the skeleton. Am J Anat 183:1-44

2. Raisz LG, Kream BE 1983 Regulation of bone formation. Med Prog 309:29-35, 83-89.

3. Somerman MJ, Fisher L.W, Foster RA, Sauk JJ 1988 Human bone sialoproteins I and II enhance fibroblast attachment in vitro. Calcif Tissue Int 43:50-53.

4. Oldber GA, Franzen A, Heinegard D 1986 Cloning and sequencing of rat bone sialoprotein (osteopontin) cDNA reveals an Arg-Gly-Asp cell binding sequence. Proc Natl Acad Sci USA 83:8819-8823.

5. Wang EA, Rosen V, D'Alessandro JS, Bauduy M, Cordes $P$, Harada T, Israel DI, Hewick RM, Kerns KM, LaPan P, Luxenberg DP, McQuaid D, Moutsatsos IK, Nove J, Wozney JM 1990 Recombinant human bone morphogenetic protein induces bone formation. Proc Natl Acad Sci USA 87: 2220-2224.

6. Beerstsen W, van den Bos T 1992 Alkaline phosphatase in duces the mineralization of sheets of collagen implanted subcutaneously in the rat. J Clin Invest 89:1974-1980.

7. Termine JD, Kleinman HK, Whitson SW, Conn KM, McGarvey ML., Martin GR 1981 Osteonectin, a bone-specific protein linking mineral to collagen. Cell 26:99-105.

8. Price PA, Parthemore JG, Deftos LJ 1980 New biochemical marker for bone metabolism. Measurements by radioimmunoassay of bone gla protein in the plasma of normal subjects and patients with bone disease. $\mathrm{J}$ Clin Invest 66:878-883.

9. Barton GJ, Newman RH, Freemont PS, Crumpton MJ 1991 Amino acid sequence analysis of the annexin super-gene family, Eur J Biochem 198:749-760.

10. Geisow MJ, Fritsche U, Hexham JM, Dash B, Johnson T $1986 \mathrm{~A}$ consensus amino-acid sequence repeat in Torpedo and mammalian $\mathrm{Ca}^{+*}$-dependent membrane-binding proteins. Nature 320:636-638.

11. Pepinsky RB, Tizard R, Mattaliano RJ, Sinclair KL, Miller GT, Browning JL, Chow EP, Burne C, Huang KS, Pratt D, Wachter L, Hession C, Frey AZ, Wallner BP 1988 Five distinct calcium and phospholipid binding proteins share homology with lipocortin 1. J Biol Chem 263:10799-10811.

12. Crumpton MJ, Dedman JR 1990 Protein terminology tangle Nature 345:212.

13. Genge BR, Wu LNY, Wuthier RE 1990 Differential fractionation of matrix vesicle proteins. Further characterization of the acidic phospholipid-dependent $\mathrm{Ca}^{+*}$-binding proteins. J Biol Chem 265:4703-4710.

14. Genge BR, Wu LNYH, Adkinsson HD, Wutheri RE 1991 Matrix vesicle annexins exhibit proteolipid-like properties. J Biol Chem 266:10678-10685.

15. Pfäffle M, Ruggiero $F$, Hofmann H, Fernandez MP, Selmin O, Yamada Y, Carrone R, von der Mark K 1988 Biosynthesis, secretion and extracellular localization of anchorin CII, a 
collagen-binding protein of the calpactin family. EMBO $\mathrm{J} 7$ 2335-2342.

16. Boskey AL, Posner AS 1977 The role of synthetic and bone extracted Ca-phospholipid-PO, complexes in hydroxyapatite formation. Calcif Tissue Res 23:25I-258.

17. Boyan BD 1985 Proteolipid-dependent calcification. In: Butler WT (ed.) The Chemistry and Biology of Mineralized Tissues. Ebsco Media, Birmingham, AL, pp. 125-131.

18. Posner AS 1987 Bone mineral and the mine:alization process. In: Peck WA (ed.) Bone and Mineral Research, Annual 5. Elsevier, Amsterdam, pp. 65-116.

19. Peck WA 1984 The effects of glucocorticoid; on bone cell metabolism and function. Adv Exp Med Biol 171:111-119.

20. Bellows CG, Heersche JNM, Aubin JE 1990 Determination of the capacity for proliferation and differentiation of osteoprogenitor cells in the presence and absence of dexamethasone. Dev Biol 140:132-138.

21. Kasugai $S$, Todescan R Jr, Nagata T, Yao KL, Butler WT Sodek J 1991 Expression of bone matrix protisins associated with mineralized tissue formation by adult rat bone marrow cells in vitro: Inductive effects of dexamethasone on the osteoblastic phenotype. J Cell Physiol 147:111-120.

22. Tenenbaum HC, Heersche JNM 1985 Dexamel hasone stimu lates osteogenesis in chick periosteum in vitro. Endocrinology 117:2211-2217.

23. Browning JL, Ward MP, Wallner BP, Pepinsky RB 1990 Studies on the structural properties of lipocortin- $I$ and the regulation of its synthesis by steroids. In: Melli M, Parente I. (eds.) Cytokines and Lipocortins in Inflammation and Differentiation. Wiley Liss, New York, pp. 27-45.

24. Flower RJ 1990 Lipocortin. In: Melli M, Parente L (eds.) Cytokines and Lipocortins in Inflammation ard Differentiation. Wiley Liss, New York, pp. 11-25.

25. Russo-Marie F 1991 Lipocortins: An update. Prostaglandins Leukot Essent Fatty Acids 42:83-89.

26. Wong G, Cohn DV 1974 Separation of parathyroid hormone and calcitonin-sensitive cells from non-responsive bone cells. Nature 252:713-715.

27. Laemmli UK 1970 Cleavage of structural proteins during the assembly of the head of bacteriophage T4. Nature 227:680685.

28. Burnette WN 1981 "Western blotting": Electrophoresis transfer of proteins from sodium dodecyl sulfate polyacrylamide gels to unmodified nitrocellulose and radiographic detection with antibody and radioiodinated protein $\mathrm{A}$. Anal Biochem 72:248-254.

29. Goudie RB, Horne CHW, Wilkinson PA 1966 A simple method for producing antibody to a single selected diffusible antigen. Lancet 2:1224.

30. Coméra C, Rothhut B, Russo-Marie F 1990 Identification and characterization of phospholipase $A_{2}$ inhititory proteins in human mononuclear cells. Eur J Biochem 188:139-146.

31. Rothhut B, Coméra C, Prieur B, Errasfa M, Minassian G, Fusso-Marie $F 1987$ Purification and characterization of a 32-kDa phospholipase $A_{2}$ inhibitory protein (lipocortin) from human peripheral blood mononuclear cells. FEBS Lett 219: 169-175.

32. Sambrook J, Fritsch EF, Maniatis T 1989 Molecular cloning. In: Nolan C (ed.) A Laboratory Manual, zind ed. Cold Spring Harbor Laboratory Press, Cold Spring Harbor, NY, pp. 7-19-7-22.

33. Virka GD, Northemann W, Schieles BR, Widera G, Broome S 1990 Simplified northern blot hybridization using $5 \%$ sodium dodecyl sulfate. Biotechniques 8:370-371.

34. Barbu V, Dautry F 1989 Northern blot normalization with 28 S rRNA oligonucleotide probe. Nucleic Acids Res 17:7115.
35. Radvanyi F, Jordan L, Russo-Marie F, Bon C 1989 A sensitive and continuous fluorometric assay for phospholipase $A_{2}$ using pyrene-labeled phospholipids in the presence of serum albumin. Anal Biochem 177:103-109.

36. Silve C, Grosse B, Tau C, Garabédian M, Fritsch J, Delmas PD, Cournot-Witmer G, Balsan S 1986 Response to parathyroid hormone and 1,25-dihydroxyvitamin $D_{3}$ of bone-derived cells isolated from normal children and children with abnormalities in skeletal development. J Clin Endocrinol Metab 62:583-590.

37. Gilman A 1970 A protein binding assay for $3^{\prime} 5^{\prime}$-cyclic adenosine monophosphate. Proc Nall Acad Sci USA 67:305-312.

38. Iyengar $R$, Birnbaumer $L 1981$ Techniques in cyclic nucleotides research. In: Schrader WT, O’Malley BW (eds.) Laboratory Methods Manual for Hormone Action and Molecular Endocrinology, Vol. 9. Biological Associates, Houston, pp. 37-38.

39. Lowry OH, Rosebrough RJ, Farr AL, Randall RJ 1951 Protein measurement with the folin phenol reagent. J Biol Chem 193:265-275.

40. Mauch C, von der Mark K, Helle O, Mollenhauer J, Pffäffle M, Krieg T 1988 A defective cell surface collagen-binding protein in dermatosparactic sheep fibroblasts. J Cell Biol 106:205-211.

41. Rojas E, Pollard HB, Haigler HT, Parra C, Burns AL 1990 Calcium-activated endonexin II forms calcium channels across acidic phospholipids bilayer membranes. $J$ Biol Chem 265:21207-21215.

42. Bienkowski MJ, Petro MA, Robinson LJ 1989 Inhibition of thromboxane A synthesis in U937 cells by glucocorticoids. J Biol Chem 264:6536-6544.

43. Hullin F, Raynal P, Ragab-Thomas JMF, Fauvel J, Chap H 1989 Effect of dexamethasone on prostaglandin synthesis and on lipocortin status in human endothelial cells. Inhibition of prostaglandin $l_{2}$ synthesis occurring without alteration of arachidonic acid liberation and of lipocortin synthesis. J Biol Chem 264:3506-3513.

44. Wong WT, Nick HS, Frost SC, 12992 Regulation of annexin $I$ in adipogenesis: CAMP-independent action of methylisobutylxanthine. Am J Physiol 262:C91-C97.

45. Solito E, Raugei G, Melli M, Parente L 1991 Dexamethasone induces the expression of the mRNA of lipocortin 1 and 2 and the release of lipocortin 1 and 5 in differentiated, but not undifferentiated U-937 cells. FEBS Lett 291:238-244.

46. Beresford JN, Gallagher JA, Poser JW, Russell RGG 1984 Production of osteocalcin by human bone cells in vitro. Effects of $1,25(\mathrm{OH})_{2} \mathrm{D}_{3}$, parathyroid hormone and glucocorticoids. Metab Bone Dis 5:229-234.

47. Silve $C$, Fritsch $J$, Grosse B, Tau C, Edelman A, Delmas $P$, Balsan S, Garabédian M 1989 Corticosteroid-induced changes in the responsiveness of human osteoblast-like cells to parathyroid hormone. Bone Miner 6:65-75.

48. Chen TL, Feldman D 1979 Glucocorticoid receptors in sub populations of cultured rat bone cells. Mechanism of dexamethasone potentiation of parathyroid hormone-stimulated cyclic AMP production. J Clin Invest 63:750-758.

49. Catherwood BD 1985 1,25-Dihydroxycholecalciferol and glucocorticosteroid regulation of adenylate cyclase in an osteoblast-like cell line. J Biol Chem 260:736-743.

50. Rizzoli R, von Tscharner V, Fleisch HF 1986 Increase of adenylate cyclase catalytic unit activity by dexamethasone in rat osteoblast like cells. Biochem J 237:447-454.

51. Rodan SB, Fisher MK, Egan JJ, Epstein PM, Rodan GA 1984 The effect of dexamethasone on parathyroid hormone stimulation of adenylate cyclase in ROS $17 / 2.8$ cells. Endocrinology 115:951-958. 
52. Yamamoto I, Potts JT, Segre GV 1988 Glucocorticoids increase parathyroid hormone receptors in rat osteoblastic osteosarcoma cells (ROS 17/2). J Bone Miner Res 3:707-712.

Address reprint requests to:

Caroline Silve CNRS URA 583

Tour Lavoisier Gème étage Hôpital Necker Enfants Malades 149 rue de Sèvres

75743, Paris Cedex 15, France

Received in original form July 30, 1992; in revised form February 17. 1993; accepted February 18, 1993. 